\title{
An Isotopic Assay for NADPH Oxidase Activity and Some Characteristics of the Enzyme
}

\section{from Human Polymorphonuclear Leukocytes}

\author{
Lawrence R. DeChatelet, Linda C. McPhail, Debra Mullikin, and \\ Charles E. McCall \\ From the Departments of Biochemistry and Medicine, The Bowman Gray \\ School of Medicine, Winston-Salem, North Carolina 27103
}

A B S T R A C T An isotopic assay for NADPH oxidase that measures the amount of NADP formed by the 6phosphogluconate dehydrogenase reaction has been developed. Under appropriate conditions, the amount of NADP present is directly proportional to the amount of ${ }^{14} \mathrm{CO}_{2}$ released from $\left[1-{ }^{14} \mathrm{C}\right] 6$-phosphogluconic acid. Because this assay employs radioisotopes, it is far more sensitive than conventional assays for the enzyme.

The human granule NADPH oxidase, as measured by this assay, is active in the presence of $\mathrm{CN}^{-}$, is stimulated by $\mathrm{Mn}^{2+}$, and has a $\mathrm{pH}$ optimum of 5.5 . Granules isolated from cells that have been allowed to ingest zymosan consistently exhibited more enzyme activity than did granules isolated from either resting cells or cells challenged with zymosan that was not preopsonized. This effect was observed over a wide range of substrate concentrations and could not be explained by differences in protein concentrations between the various samples. If whole homogenates are used in place of isolated granules, the enzyme activity can be observed only with a homogenate of phagocytizing cells and even then only at a high concentration of NADPH. This suggests that an inhibitor of the enzyme might be present within the cell. One patient with chronic granulomatous disease was studied. There was no difference in NADPH oxidase activity of the patients' cells when granules from resting and phagocytizing cells were compared. In contrast, the enzyme activity in granules from two control patients doubled upon phagocytosis. These results are consistent with a role for NADPH oxidase in the initiation of the respiratory

Dr. McCall is the recipient of Research Career Development Award AI-70767.

Received for publication 25 September 1974 and in revised form 7 December 1974. burst accompanying phagocytosis by human neutrophils.

\section{INTRODUCTION}

During the process of phagocytosis by human polymorphonuclear leukocytes (PMNL), there are pronounced changes in oxidative metabolism including increases in oxygen consumption (1), hexose monophosphate shunt (HMS) activity (1), hydrogen peroxide production (2), reduction of nitroblue tetrazolium dye (3), superoxide anion production (4), and the generation of chemiluminescence (5). That these metabolic alterations are related to the functional integrity of the cell is attested to by evidence derived from several disease states. Cells obtained from patients with chronic granulomatous disease of childhood (CGD) (6) or with severe leukocytic glucose-6-phosphate dehydrogenase deficiency (7) fail to increase their oxidative metabolism during phagocytosis; this is associated with an impaired ability to kill many types of bacteria. The bactericidal event may involve interaction of the $\mathrm{H}_{2} \mathrm{O}_{2}$ produced with a halide and myeloperoxidase, resulting in the iodination of bacterial protein (8) or peptide bond cleavage (9). Alternatively, the bactericidal activity may reside in the interaction of one or more reactive intermediates with the bacterium. Such reactive species as superoxide anion (4), singlet oxygen (5), and hydroxyl radical (10) have been suggested as candidates for the cidal mechanism.

If the precise mechanism of bactericidal activity is

1 Abbreviations used in this paper: CGD, chronic granulomatous disease; HMS, hexose monophosphate shunt; PBS, phosphate-buffered saline; PMNL, polymorphonuclear leukocytes. 
uncertain, the initial event that causes the altered oxidative metabolism is perhaps more so. Most workers agree that the initial metabolic event revolves about the activation of an oxidase enzyme by phagocytosis; two major candidates for the initial oxidase have been proposed.

Baehner and Karnovsky (11) have suggested a central role for reduced nicotinamide adenine dinucleotide NADH oxidase. They reported decreased levels of this enzyme in cells obtained from patients with CGD (11) and demonstrated that the activity of the enzyme was sufficient to account for the magnitude of the observed respiratory burst accompanying phagocytosis (12).

On the other hand, the laboratory of Patriarca, Cramer, Moncalvo, Rossi, and Romeo (13) has suggested the direct involvement of reduced nicotinamide adenine dinucleotide phosphate (NADPH) oxidase in the initiation of the respiratory burst. These workers demonstrated that NADPH oxidase of guinea pig peritoneal PMNL is activated during phagocytosis, apparently due to a shift in the $K_{m}$ of the enzyme for its substrate. This idea recently received strong support in an abstract that reported that granules obtained from normal human PMNL likewise show increased NADPH oxidase activity during phagocytosis, whereas those obtained from patients with CGD show no such effect (14).

Work on the pyridine nucleotide oxidases has been complicated by the lack of a sensitive and reproducible assay system. The assay systems traditionally used involve measuring either the uptake of oxygen by means of a Clark electrode (13) or the disappearance of reduced pyridine nucleotide by means of the absorbance at $340 \mathrm{~nm}$ (15). Both of these techniques are useful for measurement of the enzymes from guinea pig cells but are less satisfactory for the human enzymes, which are far lower in activity (16). The measurement of oxygen consumption is relatively nonspecific, and variable spontaneous (nonenzymatic) rates of oxygen consumption are obtained from day to day. The spectrophotometric determination is more sensitive, but relatively low concentrations of substrate must be utilized because of the intense absorbance of the reduced pyridine nucleotides at $340 \mathrm{~nm}$. Thus one is forced to determine the relatively low enzyme activity under conditions that may be far from optimal.

The present communication describes an isotopic assay for NADPH oxidase and outlines some of the characteristics of the enzyme from human PMNL. This assay does not measure the disappearance of a reactant but rather determines the formation of NADP, one of the products of the reaction. The NADP produced is quantitated by means of its reaction with $\left[1-{ }^{14} \mathrm{C}\right] 6$-phosphogluconate, which results in the pro- duction of ${ }^{14} \mathrm{CO}_{2}$. This assay provides a distinct advantage in sensitivity over existing procedures because of the ease of quantitating tracer amounts of ${ }^{14} \mathrm{CO}_{2}$.

\section{METHODS}

Isolation of leukocytes. Human PMNL were isolated from $90 \mathrm{ml}$ of venous blood by sedimentation of the erythrocytes with plasma gel (HTI Corp., Buffalo, N. Y.), as previously described (17). Cells were collected by centrifugation at $650 \mathrm{~g}$ for $15 \mathrm{~min}$ at $4^{\circ} \mathrm{C}$. The packed cells were washed once with $5 \mathrm{ml}$ of Dulbecco's phosphate-buffered saline (PBS). Contaminating erythrocytes were removed by hypotonic lysis for $20 \mathrm{~s}$ in $6.0 \mathrm{ml}$ of cold, deionized water; isotonicity was then restored by the addition of $2.0 \mathrm{ml}$ of $3.5 \% \mathrm{NaCl}$. The cells were collected by centrifugation and resuspended in $\mathrm{PBS}$ to give a final concentration of $1.5 \times$ $10^{8} \mathrm{PMNL} / \mathrm{ml}$. Total and differential counts were performed in a white cell counting chamber under phase microscopy; this procedure typically yielded preparations more than 90\% PMNL.

In one experiment, cells were obtained from a 2 -yr-old patient with CGD. In this case, the procedure was scaled down to work with $10 \mathrm{ml}$ of whole blood; cells were isolated from two control subjects in exact parallel. The diagnosis of CGD was based upon an inability of the patient's cells to exhibit a respiratory burst upon phagocytosis (including measurements of $\mathrm{O}_{2}$ consumption, HMS activity, and nitroblue tetrazolium reduction) and upon impaired clearance of two strains of bacteria, as determined by the plate dilution technique of Maalфe (18).

Isolation of gramules. Zymosan (ICN Nutritional Biochemicals Div., International Chemical \& Nuclear Corp., Cleveland, Ohio) was suspended in PBS to a concentration of $50 \mathrm{mg} / \mathrm{ml} .1 .0 \mathrm{ml}$ of the zymosan was diluted with $2.0 \mathrm{ml}$ of pooled serum for opsonization; the same quantity of the suspension was diluted with $2.0 \mathrm{ml}$ of PBS for control (unopsonized) particles. Both mixtures were incubated for $30 \mathrm{~min}$ at $37^{\circ}$. The zymosan was collected by centrifugation at $17,000 \mathrm{~g}$ for $10 \mathrm{~min}$ at $4^{\circ} \mathrm{C}$. The supernatant solutions were decanted, and the pellets were resuspended to $3.0 \mathrm{ml}$ with PBS to give a final concentration of $16.7 \mathrm{mg}$ zymosan $/ \mathrm{ml}$.

The isolated cells were suspended in PBS to a final concentration of $1.5 \times 10^{\mathrm{s}} \mathrm{PMNL} / \mathrm{ml}$. One part of cell suspensions was incubated with two parts of zymosan suspension (or PBS in the case of resting controls). All solutions were previously equilibrated to $37^{\circ} \mathrm{C}$ before mixing. Incubation was stopped after $3 \mathrm{~min}$ by the addition of an equal volume of cold $0.68 \mathrm{M}$ sucrose, and the contents of each flask were chilled by immersing the flasks in an ice bath. All samples were examined by phase microscopy for ingestion of particles.

In one experiment (Table II) ingestion was likewise monitored by measurement of HMS activity. In this case, the incubation was performed in the presence of $0.20 \mu \mathrm{Ci}$ $\left[1-{ }^{14} \mathrm{Clglucose}\right.$ (New England Nuclear, Boston, Mass. Sp act $7.5 \mathrm{mCi} / \mathrm{mmol}$ ), and ${ }^{14} \mathrm{CO}_{2}$ liberated during the course of the 3 -min incubation was collected and quantitated as previously described (19).

Each sample was homogenized to over $90 \%$ cell breakage, as monitored by phase microscopy. Homogenization was accomplished in the cold with a motor-driven Potter-Elvejhem homogenizer with a Teflon pestle. The motor, a Tri-R Stirrer Model S63-C (Tri-R Instruments, Inc., Rockville Center, N. Y.), was driven at maximum speed, 12,000 rpm; 

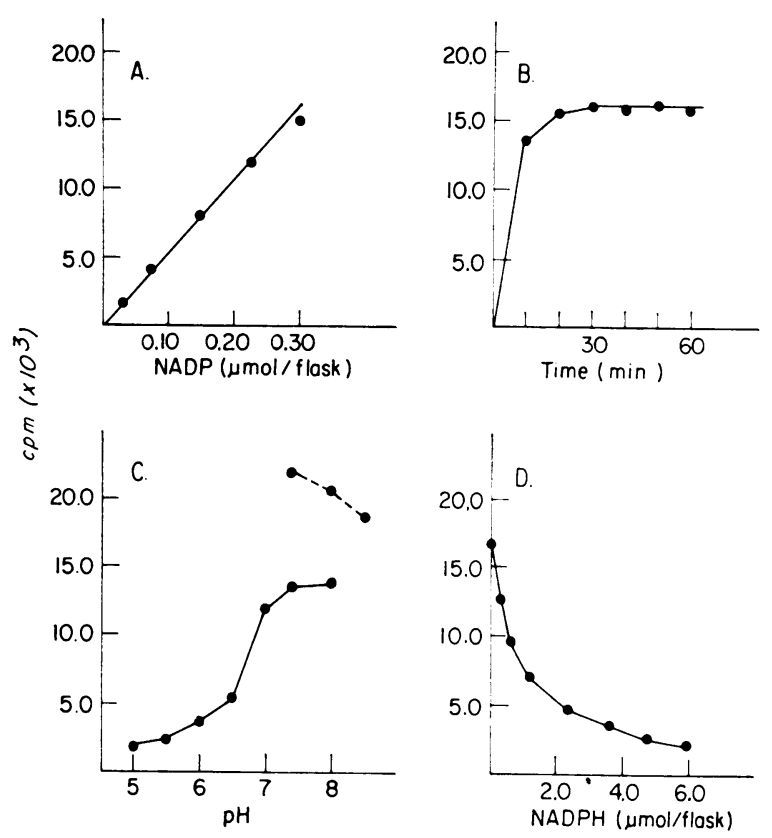

Figure 1 Assay for NADP with the 6-phosphogluconate dehydrogenase reaction. Each point is the mean of closely agreeing triplicate determinations, $\mathrm{A}$, effect of NADP concentration. B, effect of incubation time. $\mathrm{C}$, effect of $\mathrm{pH}$. solid line, phosphate buffer; dotted line, Tris $\cdot \mathrm{HCl}$ buffer. $\mathrm{D}$, inhibition of reaction by NADPH. The concentration of NADP was held constant at $0.3 \mu \mathrm{mol} /$ flask.

the homogenizer itself was of $10 \mathrm{ml}$ capacity and was obtained from Arthur H. Thomas Co., Philadelphia, Pa. Typically, the cells incubated with opsonized zymosan ruptured more readily (2-3 min homogenization time) than either the resting cells or the cells incubated with unopsonized zymosan (4-5 min homogenization time).

The homogenates were centrifuged at $250 \mathrm{~g}$ for $15 \mathrm{~min}$ in the cold to remove unbroken cells, nuclei, cell debris, and zymosan. The supernate was recentrifuged at $27,000 \mathrm{~g}$ for $15 \mathrm{~min}$, and the pellet was resuspended in a volume of $0.34 \mathrm{M}$ sucrose equal to twice the original cell volume, yielding a protein concentration of $1.0-2.0 \mathrm{mg} / \mathrm{ml}$. This preparation, substantially free of zymosan particles as judged by phase microscopy, is subsequently referred to as the granule

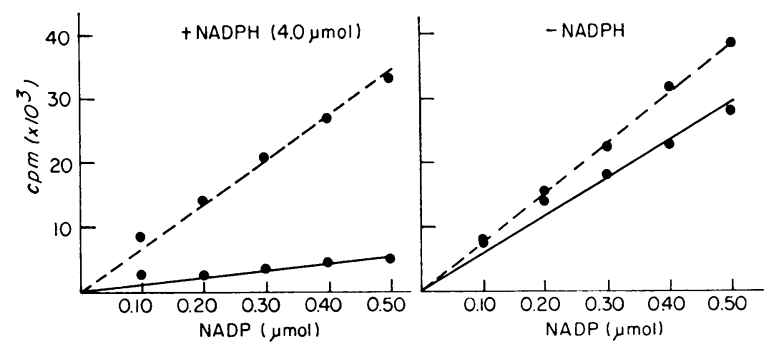

FIGURE 2 Effect of 6-phosphogluconate dehydrogenase concentration on isotopic assay for NADP. Each point represents the mean of triplicate determinations. Incubation time $30 \mathrm{~min}$. Solid line, $0.10 \mathrm{U}$ 6-PGA DH/flask; dotted line, $1.0 \mathrm{U}$ 6-PGA DH/flask. fraction. The composition of this fraction is ill-defined, but it probably consists of cell membrane material as well as true granules from the PMNL.

Protein assays on the various granule samples were performed by the method of Lowry, Rosebrough, Farr, and Randall (20). Each sample was assayed at three different levels of protein and the results were averaged. Standards consisting of both bovine serum albumin and lysozyme were run concurrently with the unknown samples, and the results with the two different proteins were averaged for all calculations. Values obtained with lysozyme as a standard are routinely greater (1.4-fold) than those obtained with albumin. This procedure partially compensates for the fact that the same quantity of different proteins yields a different degree of color formation in the Lowry procedure, due to the varying amino acid composition.

Assay for NADPH oxidases activity. A two-step incubation procedure was employed. In the first step, the following materials were incubated in a total volume of $1.0 \mathrm{ml}$ : $0.1 \mathrm{M}$ potassium phosphate buffer, $\mathrm{pH}$ 5.5. $0.5 \mathrm{mM} \mathrm{MnCl}_{2}$; $1.25 \mathrm{mM} \mathrm{NADPH} ; 2.0 \mathrm{mM} \mathrm{KCN}$; and $0.10 \mathrm{ml}$ of the appropriate granule fraction (containing $0.10-0.20 \mathrm{mg}$ protein). Tubes were incubated at $37^{\circ} \mathrm{C}$ for $30 \mathrm{~min}$; the incubation was terminated by the addition of $0.50 \mathrm{ml}$ of $0.20 \mathrm{~N} \mathrm{HClO}_{4}$. The solution was neutralized by the addition of $0.50 \mathrm{ml}$ of $0.20 \mathrm{~N}$ $\mathrm{KOH}$. The samples were centrifuged in a clinical centrifuge, and the supernates were assayed for NADP.

The second step in the assay was performed in $50 \mathrm{ml}$ Erlenmeyer flasks. Each flask contained in a total volume of $3.0 \mathrm{ml}: 1.80 \mathrm{ml}$ Tris $\mathrm{HCl}$ buffer $(0.10 \mathrm{M}, \mathrm{pH} 7.4) ; 1.0-\mathrm{ml}$ sample of the appropriate supernate from the first incubation; $0.10 \mu \mathrm{Ci}(2.5 \mu \mathrm{mol})$ of $\left[1-{ }^{14} \mathrm{C}\right] 6$-phosphogluconic acid (New England Nuclear) and $1.0 \mathrm{U}$ of 6-phosphogluconic acid dehydrogenase (Sigma Chemical Co., St. Louis, Mo.). Reaction was started by the addition of the enzyme and was allowed to proceed for $30 \mathrm{~min}$ at $37^{\circ} \mathrm{C} .{ }^{14} \mathrm{CO}_{2}$ liberated during the course of the incubation was trapped in a center well containing $0.50 \mathrm{ml}$ hydroxide of hyamine. Reaction was terminated by the addition of $1.0 \mathrm{ml}$ of $5 \%$ trichloroacetic acid, and the ${ }^{14} \mathrm{CO}_{2}$ was quantitated by liquid scintillation spectrometry, as previously described (20).

Initial experiments that delineated these conditions are described under Results.

\section{RESULTS}

The first part of the research was concerned with establishing the 6-phosphogluconate dehydrogenase reaction as a valid assay system for NADP. Fig. 1 illustrates some of the characteristics of this reaction. The evolution of ${ }^{14} \mathrm{CO}_{2}$ from $\left[1{ }^{14} \mathrm{C}\right] 6$-phosphogluconic acid is directly proportional to the NADP concentration up to at least $0.3 \mu \mathrm{mol} \mathrm{NADP} /$ flask (Fig. 1A). The reaction is essentially complete within $20 \mathrm{~min}$ (Fig. 1B) and is optimally active in a neutral $\mathrm{pH}$ range (Fig. 1C). A major problem arose, however, with the observation that NADPH could strongly inhibit the reaction (Fig. 1D). With no NADPH present, more than $16,000 \mathrm{cpm}$ were obtained with $0.30 \mu \mathrm{mol}$ of NADP. In the presence of $2.0 \mu \mathrm{mol}$ of NADPH, the same concentration of NADP yielded less than 5,000 $\mathrm{cpm}$. This situation is unacceptable if the reaction is to serve as an assay procedure for NADPH oxidase, 
since there would be a substantial amount of unreacted NADPH in the sample assayed for NADP.

The previous experiments were performed with a concentration of $0.1 \mathrm{U}$ of 6-phosphogluconic acid dehydrogenase per flask. We found that by increasing the enzyme concentration 10 -fold, we could effectively relieve the inhibition by NADPH. Fig. 2 illustrates that increasing the enzyme concentration in the absence of $\mathrm{NADPH}$ has relatively little effect; however, in the presence of $4.0 \mu \mathrm{mol}$ of $\mathrm{NADPH}$, it causes a marked increase in the sensitivity of the reaction. In fact, in the presence of $1.0 \mathrm{U}$ of enzyme, the addition of 4.0 $\mu \mathrm{mol}$ of NADPH has almost no effect on the reaction, whereas it causes more than $85 \%$ inhibition at the lower concentration of enzyme. Further, the reaction is very linear with respect to NADP concentration up to at least $0.50 \mu \mathrm{mol} / \mathrm{flask}$, even in the presence of 4.0 $\mu \mathrm{mol}$ of the reduced form.

Fig. 3 illustrates the time course of the reaction at the two levels of enzyme. This experiment utilized 0.30 $\mu \mathrm{mol} \mathrm{NADP}$ and $4.0 \mu \mathrm{mol} \mathrm{NADPH} /$ flask. Again, the marked difference in sensitivity is apparent. Further, an incubation time of $30 \mathrm{~min}$ is required to ensure that all of the NADP present is detected.

These experiments indicated that under the conditions outlined in Methods, we could quantitatively detect NADP in the presence of NADPH and thus that the procedure could be used to measure the generation of NADP by NADPH oxidase.

Accordingly, we measured the activity of $\mathrm{NADPH}$ oxidase in granules isolated from resting cells, cells challenged with unopsonized zymosan, and cells challenged with opsonized zymosan. These experiments utilized the two-step incubation procedure described in Methods, except that a lower concentration $(0.17 \mathrm{mM})$ of NADPH was employed. The results of seven individual experiments are tabulated in Table I. There is consistently a two- to threefold increase in the activity of NADPH oxidase in granules obtained from cells challenged with opsonized zymosan, as opposed to unopsonized particles, although there is considerable variation in the absolute values on a day-to-day basis. There is no consistent difference between the results with resting granules and those with granules obtained from cells challenged with unopsonized zymosan. The results are qualitatively the same if the data are expressed in terms of specific activity $(\mathrm{cpm} / \mathrm{mg})$, indicating that the differences cannot be ascribed to a shift in total protein in the fractions. In fact, the protein values obtained in any one experiment were virtually identical for all three classes of granules.

Phagocytosis was evaluated in all experiments by phase microscopy. In every case, the cells incubated with opsonized zymosan were seen to be filled with

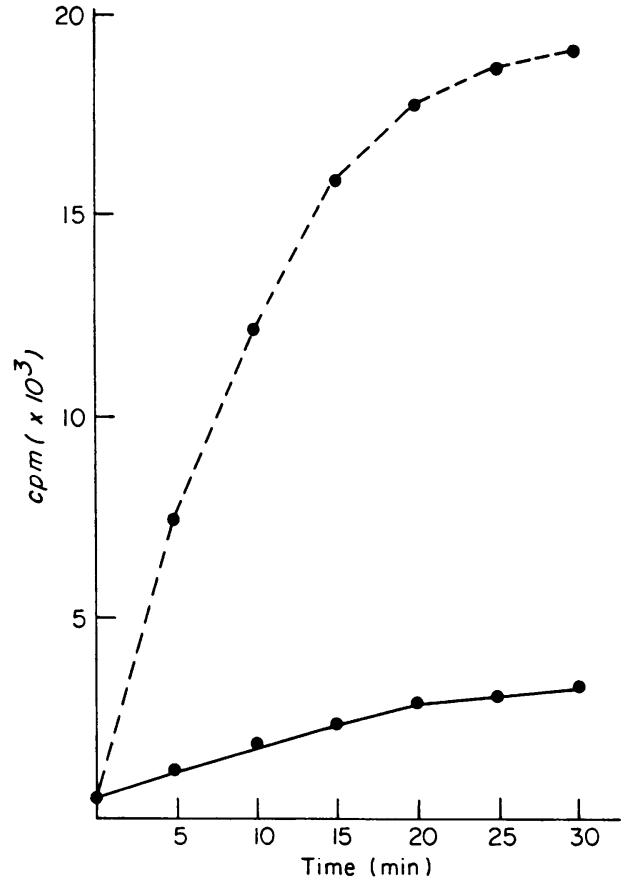

FIGURE 3 Effect of incubation time on isotopic assay for NADP. Each point represents the mean of triplicate determinations. Solid line, 0.10 U 6-PGA DH/flask; dotted line, $1.0 \mathrm{U}$ 6-PGA DH/flask.

particles after the 3-min incubation. In contrast, unopsonized zymosan particles were very rarely observed within cells. In a single experiment, we determined HMS activity using $\left[1-{ }^{14} \mathrm{C}\right]$ glucose during the course of the 3-min incubation. The results (Table II) clearly demonstrate a substantial difference in the degree of ingestion of the opsonized zymosan as opposed to the

TABLE I

NADPH Oxidase Activity in Isolated Granules from Human PMNL

\begin{tabular}{rrcrrrr}
\hline $\begin{array}{c}\text { Exp. } \\
\text { no. }\end{array}$ & \multicolumn{2}{c}{ Resting } & \multicolumn{2}{c}{$\begin{array}{c}\text { Unopsonized } \\
\text { zymosan }\end{array}$} & \multicolumn{2}{c}{$\begin{array}{c}\text { Opsonized } \\
\text { zymosan }\end{array}$} \\
\hline & $c p m$ & $c p m / m g$ & $c p m$ & $c p m / m g$ & $c p m$ & $c p m / m g$ \\
1 & 380 & 2,923 & 292 & 2,433 & 1,023 & 7,578 \\
2 & 36 & 269 & 155 & 1,158 & 884 & 5,703 \\
3 & - & - & 589 & 4,090 & 1,322 & 8,993 \\
4 & 157 & 1,931 & 342 & 4,207 & 724 & 8,905 \\
5 & - & - & 731 & 4,430 & 1,858 & 8,407 \\
6 & 155 & 1,907 & 330 & 4,059 & 1,007 & 12,387 \\
7 & 95 & 1,267 & 58 & 829 & 1,017 & 6,872 \\
\hline
\end{tabular}

NADPH oxidase activity was determined with the coupled enzyme reaction employing $\left[1-{ }^{14} \mathrm{C}\right] 6$-phosphogluconate, as described under Methods. All values have been corrected for nonenzymatic oxidation (average of 10 control determinations, $1,179 \mathrm{cpm}$ ). Each value represents the mean of closely agreeing triplicate determinations. 
TABLE II

Measurement of Phagocytosis by Human PMNL

\begin{tabular}{lcc}
\hline \multirow{2}{*}{ Conditions } & \multicolumn{2}{c}{ Degree of phagocytosis } \\
\cline { 2 - 3 } & $\begin{array}{l}\text { Microscopic } \\
\text { observation }\end{array}$ & $\begin{array}{c}\text { HMS } \\
\text { activity }\end{array}$ \\
\hline Resting cells & - & $c p m$ \\
Unopsonized zymosan* & - & 893 \\
Opsonized zymosan* & ++++ & 1,340 \\
\hline
\end{tabular}

* The extent of phagocytosis was qualitatively determined by phase microscopic observation after a 3 -min incubation, and was quantitatively determined by measurement of oxidation of $\left[1{ }^{14} \mathrm{C}\right]$ glucose (HMS activity), as described in Methods. In the latter case, each value represents the mean of closely agreeing triplicate determinations.

unopsonized particles. These results suggest that activation of the NADPH oxidase is related to the process of phagocytosis.

Fig. 4 illustrates the effect of increasing concentrations of NADPH on the oxidase activity of PMNL granules. These values are corrected for spontaneous oxidation, which increased linearly over the entire range of NADPH studied. Granules obtained from cells actively phagocytizing zymosan showed greater activity than those from cells not ingesting particles at all concentrations of NADPH studied. The protein content of the two suspensions of granules was identical, and so precisely the same pattern is observed if one plots specific activity versus NADPH concentration.

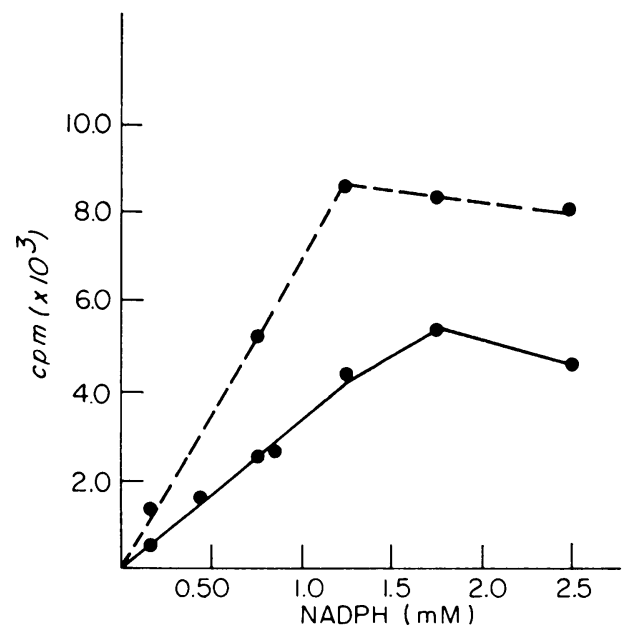

Figure 4 Effect of NADPH concentration on NADPH oxidase activity. Dotted line, granules from cells challenged with opsonized zymosan; solid line, granules from cells incubated with unopsonized zymosan. All points have been corrected for nonenzymatic oxidation and represent the mean of triplicate determinations.
Some of the characteristics of the oxidase activity of granules obtained from phagocytizing cells are indicated in Fig. 5. The enzyme activity is stimulated by the addition of $\mathrm{Mn}^{2+}$ and shows optimal activity at $\mathrm{pH}$ 5.5. The enzyme activity is not linear with respect to either protein concentration (Fig. 6A) or incubation time (Fig. 6B). These values have been corrected for nonenzymatic oxidation, which does increase linearly with respect to time of incubation. The reasons for the lack of linearity in Fig. 6 are unknown, but the importance of carefully controlling the protein content of the different granule samples is readily apparent.

Fig. 7 compares the oxidase activity in isolated granules with that observed in the whole homogenate, as a function of NADPH concentration. For the isolated granules, the granules obtained from resting cells always demonstrated oxidase activity in excess of the spontaneous activity, and the activity was further increased when granules obtained from cells incubated with opsonized zymosan were utilized. The protein content of the two types of granules was virtually identical, so the same pattern is observed when the data are plotted in terms of specific activity.

The situation is quite different if one attempts to measure the oxidase activity in the whole homogenate. In these experiments, the rate of spontaneous oxidation is comparable to that observed in the experiments uti-

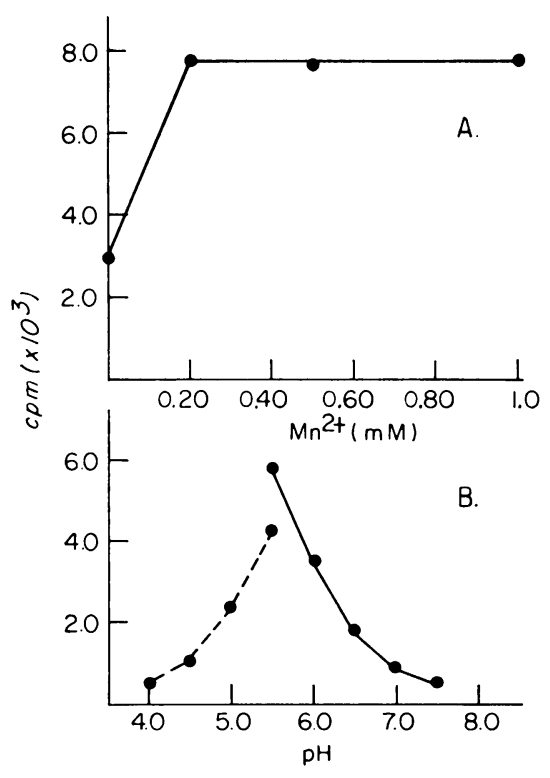

Figure 5 Characteristics of NADPH oxidase from human PMNL. Granules were obtained from cells challenged with opsonized zymosan; all values are corrected for nonenzymatic oxidation and represent the mean of triplicate determinations. A, effect of $\mathrm{Mn}^{2+}$ concentration. $\mathrm{B}, \mathrm{pH}$ optimum of the reaction. Dotted line, acetate buffer; solid line, phosphate buffer. 


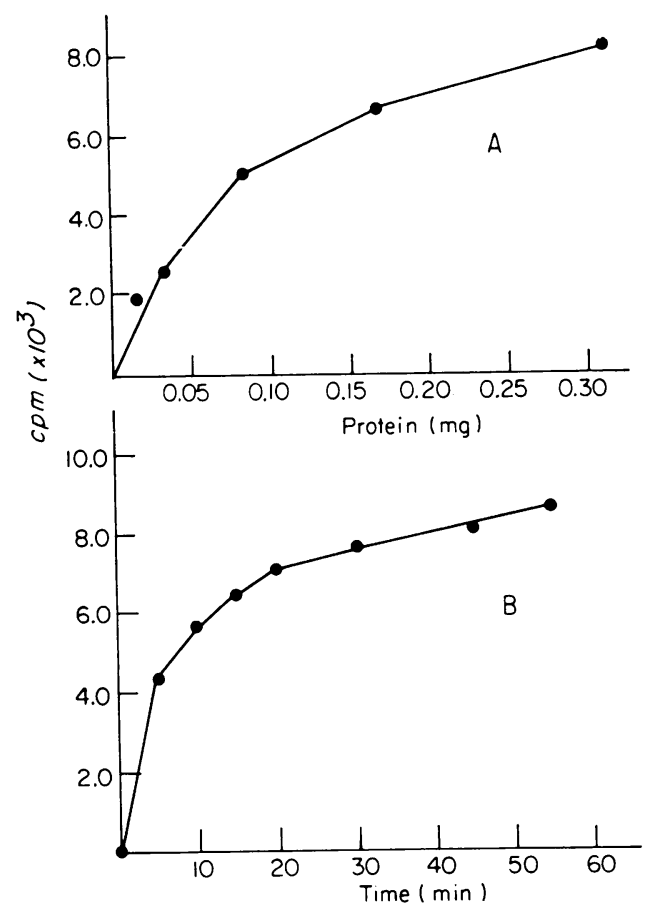

Figure 6 Effect of protein concentration (A) and of incubation time (B) on NADPH oxidase activity. Granules were obtained from cells challenged with opsonized zymosan; all values are corrected for nonenzymatic oxidation and represent the mean of triplicate determinations.

lizing isolated granules. The addition of whole homogenate, however, results in a marked inhibition of the spontaneous oxidation. In the case of homogenate obtained from resting cells, this inhibition is observed at all levels of substrate examined. The inhibition is quite dependent on concentration of NADPH when the homogenate is derived from cells actively ingesting zymosan. At low substrate concentrations, the inhibition is almost as complete as with granules from resting cells. However, at higher concentrations of NADPH, the inhibition is less apparent, and in one case (exp. 1) some oxidase activity in excess of the spontaneous oxidation can be observed at an NADPH concentration of $0.85 \mathrm{~m}$.I.

Fig. 8 compares the oxidase activity of granules obtained from the cells of a patient with CGD to that of granules obtained from two normal controls. Because of the small amount of blood available from the patient, it was necessary to use a substantially smaller amount of cellular material in each incubation flask; this experiment utilized a concentration of NADPH of $1.25 \mathrm{mM}$. The data indicate that both controls show an increase in enzyme activity upon phagocytosis but the CGD cells do not. The virtually normal activity in
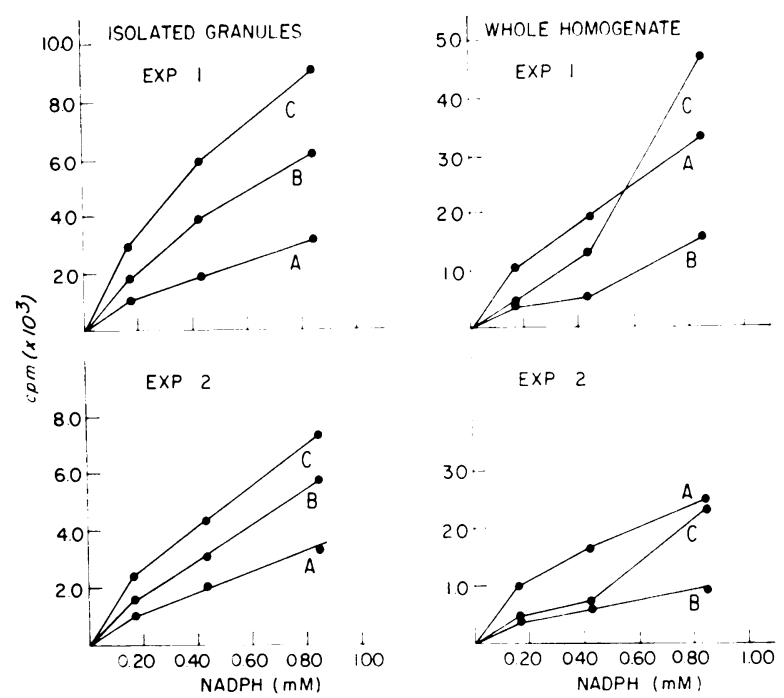

FigCre 7 Comparison of NADPH oxidase activity in isolated granules and whole homogenates of human PMNL. Two separate experiments are illustrated; each point was determined in triplicate in each experiment. A, spontaneous oxidation; no protein added. B, isolated granules or whole homogenate from cells challenged with unopsonized zymosan. C, Isolated granules or whole homogenate from cells challenged with opsonized zymosan.

the resting CGD sample suggests a defect in activation of the enzyme rather than in absolute amount.

\section{DISCUSSION}

We have devised a sensitive isotopic assay for the measurement of NADPH oxidase activity and have employed this assay to investigate some of the characteristics of the enzyme from human PMNL, utilizing the assay conditions of Hohn and Lehrer (14), which are adapted from the methods of Patriarca et al. (13).

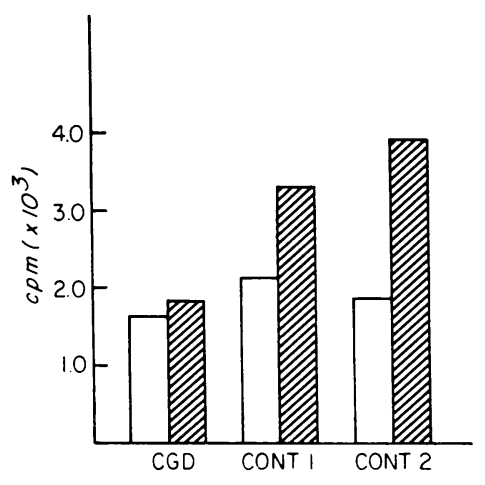

Figure 8 NADPH oxidase activity of isolated PMNL granules abtained from two normal controls and from one patient with CGD. All values were determined in triplicate; each is corrected for spontaneous oxidation. Open bars, granules isolated from resting cells; hatched bars, granules isolated from cells challenged with preopsonized zymosan. 
We utilized a granule fraction from homogenized cells as a source of the enzyme and ran all assays in the presence of $\mathrm{CN}^{-}$, since the respiratory burst is, itself, $\mathrm{CN}^{-}$-insensitive.

Under these conditions, we consistently observed a higher enzyme activity with granules obtained from cells allowed to ingest opsonized zymosan as compared to cells incubated without zymosan or with zymosan that had not been opsonized (Table I and Figs. 4 and 7). This increased activity was not altered when the data were calculated per milligram of protein, indicating that an intracellular shift in protein concentration would not provide a satisfactory explanation. The activity of NADPH oxidase increases very rapidly upon interaction of the cell with the opsonized zymosan, as indicated by the extremely short duration $(3 \mathrm{~min})$ of the incubation. This is consistent with a role for the enzyme in initiation of the respiratory hurst. Further, the activation of the enzyme correlates with the process of phagocytosis as judged by either direct microscopic observation or by measurement of HMS activity with $\left[1{ }^{14} \mathrm{C}\right]$ glucose (Table II).

Some of the properties of the enzyme are of interest. The apparent activation by phagocytosis is observed at all levels of NADPH examined (Fig. 4). The enzyme requires exogenous $\mathrm{Mn}^{2+}$ for optimal activity and exhibits maximal activity at $\mathrm{pH} 5.5$, in accord with the observations of Patriarca et al. (13), using guinea pig PMNL, and of Hohn and Lehrer (14), using human PMNL. The requirement for an exogenous source of $\mathrm{Mn}^{2+}$ is currently open to question, however, since no one has reported the intracellular concentration of this ion within the PMNL.

The activity of the granule enzyme from phagocytizing cells is not linear with respect to either protein concentration or time of incubation (Fig. 6). The reasons for this lack of linearity are not presently known, but they may be related to inhibition of the enzyme by $\mathrm{H}_{2} \mathrm{O}_{2}$ (a product of the reaction) or to the presence of an endogenous inhibitor in the preparation. The lack of linearity certainly explains some of the difficulties encountered in assaying for the enzyme and emphasizes that rigid control of both protein concentration and incubation time is necessary to compare the activities of different samples. We are presently engaged in attempting to define conditions under which the activity of the enzyme will be linear with respect to both time and protein concentration.

Fig. 7 compares the activity in isolated granules with that in the corresponding whole homogenate as a function of NADPH concentration. In the isolated granules the activity of granules obtained from resting cells is always higher than the spontaneous oxidation, and the activity of granules from phagocytising cells is higher still. The situation is far more complex in the case of the whole homogenates. The activity of the homogenate from resting cells is lower than the spontaneous activity at all levels of NADPH tested. Not only can no enzyme activity be measured under these conditions, but the auto-oxidation of NADPH is reduced. When whole homogenate from phagocytizing cells is employed, the results are variable. At low concentrations of NA$\mathrm{DPH}$, there is an inhibition of the spontaneous oxidation, as seen with the resting homogenate. However, this inhibition is less pronounced as the concentration of NADPH is increased, and in one experiment some enzyme activity was measurable at the highest concentration $(0.85 \mathrm{mM})$. One explanation for these results is that the cell contains an inhibitor of NADPH oxidase that prevents the activity of the enzyme from being expressed. The increased enzyme activity observed in granules from phagocytizing cells might be a result of relieving this inhibition. Alternatively, it is possible that there is both an enzyme and a substrate that reduce NADP in the whole homogenate. Future experiments will attempt to clarify these possibilities.

Fig. 8 illustrates the results of one experiment employing cells from a patient with CGD. The NADPH oxidase activity of resting granules from the patient's cells was not substantially different from that of the control granules; however, the activity did not increase when the CGD cells were incubated with opsonized zymosan, in contrast to the controls, which demonstrated at least a twofold increase in activity upon phagocytosis. Because of the small number of cells available, protein values were not determined for the various granules; however, the similarity in activities of the granules obtained from resting CGD and control cells would indicate that there were no major differences in protein concentration. Although the results of this single experiment certainly can not be accepted as conclusive, they are in complete agreement with those reported by Hohn and Lehrer (14). Thus, it seems plausible that the initiation of the respiratory burst might be mediated by activation of a granule NADPH oxidase and that failure of this activation phenomenon might be the underlying defect in CGD. It should be recognized that the present communication provides no direct evidence that the enzyme per se is activated, and alternative explanations based on permeability changes or translocation of the enzyme are possible.

One disadvantage to the present assay system is that it is specific for NADPH oxidase and cannot be adapted to measure $\mathrm{NADH}$ oxidase activities because of the specificity of the 6-phosphogluconate dehydrogenase reaction. Thus, it is impossible to test directly the observations of others $(11,12)$ that there is a deficiency of NADH oxidase in CGD cells in this assay system. 
One possibility might reconcile the divergent opinions; in the human PMNL a single oxidase might utilize either NADH or NADPH as substrate. The only purification of oxidase enzymes reported involves a 50 fold purification of NADH oxidase from guinea pig peritoneal PMNL (21). That enzyme showed no demonstrable activity towards NADPH (21), but the situation may be quite different in human PMNL. The present assay should prove invaluable for purifying the NADPH oxidase from human PMNL; it should be relatively easy then to test the semipurified enzyme for $\mathrm{NADH}$ oxidase activity by conventional means.

\section{ACKNOWLEDGMENTS}

We are indebted to Drs. David Hohn and Robert Lehrer for their open discussion of their unpublished data and to Drs. Jimmy Simon and Doris Sanders for allowing us to study their patient with CGD.

This research was supported by a grant from the Forsyth Cancer Service and by Public Health Service Grants Al10732 and Al-09169 from the National Institute of Allergy and Infectious Disease, and CA-12197 from the National Cancer Institute.

\section{REFERENCES}

1. Sbarra, A. J., and M. L. Karnovsky. 1959. The biochemical basis of phagocytosis. I. Metabolic change during the ingestion of particles by polymorphonuclear leukocytes. J. Biol. Chem. 234: 1355-1362.

2. Iyer, G. Y. N., M. F. Islam, and J. H. Quastel. 1961. Biochemical aspects of phagocytosis. Nature (Lond.). 192 : 535-541.

3. Baehner, R. L., and D. G. Nathan. 1968. Quantitative nitroblue tetrazolium test and chronic granulomatous disease. N. Engl. J. Med. 278: 971-976.

4. Babior, B. M., R. S. Kipnes, and J. T. Curnutte. 1973. Biological defence mechanisms. The production by leukocytes of superoxide, a potential bactericidal agent. $J$. Clin. Invest. 52: 741-744.

5. Allen, R. C., R. L. Stjernholm, and R. H. Steele. 1972. Evidence for the generation of an electronic excitation state(s) in human polymorphonuclear leukocytes and its participation in bactericidal activtiy. Biochem. Biophys. Res. Commun. $47: 679-684$.

6. Holmes, B., A. R. Page, and R. A. Good. 1967. Studies of the metabolic activity of leukocytes from patients with a genetic abnormality of phagocytic function. $J$. Clin. Invest. 46: 1422-1432.

7. Cooper, M. R., L. R. DeChatelet, C. E. McCall, M. F. LaVia, C. L. Spurr, and R. L. Baehner. 1972. Complete deficiency of leukocyte glucose-6-phosphate dehydroge- nase with defective bactericidal activity. J. Clin. In'est. 51: 769-778

8. Klebanoff, S. J. 1967. Iodination of bacteria: a bactericidal mechanism. J. Exp. Med. 126: 1063-1078 and plate 80.

9. Selvaraj, R. J., B. B. Paul, R. R. Strauss, A. A. Jacobs, and A. J. Sbarra. 1974. Oxidative peptide cleavage and decarboxylation by the $\mathrm{MPO}-\mathrm{H}_{2} \mathrm{O}_{2}-\mathrm{Cl}^{-}$antimicrobial system. Infect. Immun. 9: 255-260.

10. Webb, L. S., B. B. Keele, Jr., and R. B. Johnston, Jr. 1974. Inhibition of phagocytosis-associated chemiluminescence by superoxide dismutase. Infect. Immun. 9: 10511056.

11. Baehner, R. L., and M. L. Karnovsky. 1968. Deficiency of reduced nicotinamide adenine dinucleotide oxidase in chronic granulomatous disease. Science (Wash.D.C.). 162: $1277-1279$.

12. Karnovsky, M. L. 1973. Chronic granulomatous disease - pieces of a cellular and molecular puzzle. Fed. Proc. 32: $1527-1533$

13. Patriarca, P., R. Cramer, S. Moncalvo, F. Rossi, and D. Romeo. 1971. Enzymatic basis of metabolic stimulation in leukocytes during phagocytosis: the role of activated NADPH oxidase. Arch. Biochem. Biophys. 145 : 255-262.

14. Hohn, D. S., and R. I. Lehrer. 1974. Identification of the defect in $\mathrm{x}$-linked chronic granulomatous disease. Clin. Res. 22: 394a. (Abstr.)

15. Holmes, B., and R. A. Good. 1972. Metabolic and functional abnormalities of human neutrophils. In Phagocytic Mechanisms in Health and Disease. R. C. Williams, Jr., and H. H. Fudenberg, editors. Intercontinental Medical Book Corporation, New York. 51-66.

16. Baehner, R. L., N. Gilman, and M. L. Karnovsky. 1970. Respiration and glucose oxidation in human and guinea pig leukocytes: comparative studies. J. Clin. Invest. 49: 692-700.

17. DeChatelet, L. R., and M. R. Cooper. 1970. A modified procedure for the determination of leukocyte alkaline phosphatase. Biochem. Med. 4: 61-68.

18. Maaløe, O. 1946. On the relation of alexin and opsonin. Munksgaard, A/S, Copenhagen. 186 pp.

19. DeChatelet, L. R., M. R. Cooper, and C. E. McCall. 1971. Dissociation by colchicine of the hexose monophosphate shunt activation from the bactericidal activity of the leukocyte. Infect. Immun. 3: 66-72.

20. Lowry, O. H., N. J. Rosebrough, A. L. Farr, and R. J. Randall. 1951. Protein measurement with the Folin phenol reagent. J. Biol. Chem. 193: 265-275.

21. Karnovsky, M. L., S. Simmons, M. J. Karnovsky, J. Noseworthy, and E. A. Glass. 1972. Comparative studies on the metabolic basis of bactericidal activity in leukocytes. In Phagocytic Mechanisms in Health and Disease. R. C. Williams, Jr., and H. H. Fudenberg, editors. Intercontinental Medical Book Corporation, New York. 67-82. 